\title{
English as a World Language
}

Richard W. Bailey \& Manfred Gorlach (editors), Ann Arbor: University of Michigan Press. 1982 (1985).

Reviewed by

Edmund A. Anderson

This collection is an adequate, but not quite complete survey of work documenting the spread of English into all parts of the globe, with its resulting transformations during the course of that spread. There are 15 different contributors to this volume.

The contributions are historically enlightening and can create an awareness of the social phenomena characteristic of this movement, one of the most common of which was and is the uneasiness of the speakers of "new Englishes" in comparison with speakers of established varieties.

The "Introduction" focuses on what the reviewer feels is the key to the spread of English: the attitudes of the speakers of English, and especially of its new users, towards the language. The work of the Ugandan scholar, Ali A. Mazrui (1973:68), in comparing the impact of English and French on nation-building in Africa is cited:

The English language, by the very fact of being emotionally more neutral than French, was less of a hindrance to the emergence of national consciousness in British Africa.

Following in this same vein, the editors raise the point that, in general, "writers and speakers of English are less inclined to let respect for the language interfere with their desire to use it. One consequence of this difference in attitudes is that French is generally more uniform across the world ...., while English has developed a series of distinct national standards." These statements are worthy of further thought.

The editors rightly focus on the concern about standardization which is felt across the Englishspeaking world, and which has become the bane of existence for many governmental leaders who wish to use English in devleopment. The tendency for users of English to adapt it and claim it as their own, counter to the wishes of development planners in many cases, is manifest repeatedly in the stories of these new Englishes. If this is true, and if we follow the logic of the argument, the development of "new Englishes" is due to the lack of possessiveness on the part of the 
speakers of the established Englishes which enables the "new Englishes" to become established, Kachru's opposing view notwithstanding. This presents an interesting paradox in that the language whose speakers are most insistent on accepted standards ( $=$ French) does not appeal as widely as the language whose speakers are more accepting of local variations (= English), but the very reason for English's popularity creates frustrations for planners in the maintenance of standards.

The brief section entitled "The Phonetic Alphabet', complete with diagrams and consonant and vowel charts, will be useful for the serious scholar, but may be skipped by the reader interested primarily in familiarizing himself with the sociocultural settings for the development of the new Englishes.

Charles V.J. Russ's "The Geographical and Social Variation of English in England and Wales" should be required reading for language planners, program administrators and English teachers throughout Southeast Asia. It calls into question two assumptions people seem to have, one of which is that the British (Pygmalion and "My Fair Lady", notwithstanding) all speak Standard English with Recieved Pronunciation (RP), and, furthermore, that this has always been so. In showing that this is not so, Russ cites Hughes and Trudgill's (1979:3) estimate that "only about $3 \%$ of the English population speak RP." What may surprise some readers is that RP, supposed by many an English teacher to be a uniform, unchanging standard of pronunciation, is in reality "not entirely uniform and shows variation according to age, region, and style." Examples of intergenerational variation are labeled "Old-fashioned"' vs. "Neutral" vs. "Innovative", but all are RP.

When "falling standards of English" are being decried and the cry for greater support of standards becomes more intense, this article provides a perspective on a customary array of dialects and accents, indeed, in the country of its origin.

Historical development of English from Old English (750-1150), Middle English (1150-1500), The Development of a Standard Enlgish, Early Modern English (1500-1700) and Late Modern English (1700Present) is presented in an interesting manner. As with all contributions, there is a map for the reader unfamiliar with geography.

What was new to the reviewer was the claim of regional variation within RP, viz. the introduction of the term "Northern RP" . This is not claimed by other treatments, eg. Hughes and Trudgill (1979), where such variation is labeled regional dialect variation.

Suzanne Romaine's "The English Language in Scotland" 
presents a good case study of conflict generated by foreign incursions and attempts to maintain pre-incursion culture by, among other things, maintenance of the Gaelic and Scots languages. Romaine's reference to Macauley's study of English in Glasgow is reassuring, since Macauley's study represents a high quality example of quantitative sociolinguistics. Would the other sections in this volume were so solidly founded.

The Scots situation highlights the dedication of a local scholarly tradition at work on the problem of digesting external influences impingin upon them. This is especially relevant to Southeast Asian English speaking situations, because Scottish scholars have responded to the challenge of how to speak English but remain a Scot.

Michael V. Barry's "The English Language in Ireland" presents dialect research results. There is no mention of the quantitative methods used in writing many of the papers which appeared recently in the BELFAST WORKING PAPERS IN LANGUAGE AND LINGUISTICS, but the treatment neverthless, does provide a view into that language situation.

Richard W. Bailey's "The English Language in Canada" is rich in historical background, which brings out differences and similarities of the Canadian experience with that of the United
States. The Canadians have one of the most difficult struggles to maintain their identity of any users of a variety of English because of a common border with the United States of several thousand miles.

Frederic G. Cassidy's "Geographical Variation of English in the United States" is essentially a summary of work on the American Dialect Atlas. Recently, this situation has received its shares of criticism from urban dialect researchers. Nevertheless, the inclusion of the contribution is justified in that the dialect atlas tradition has contributed notably to an understanding of the American westward migration as reflected in the speech of descendants of the pioneers of 100 years or so later.

Thomas E. Toon's "Variation is Contemporary American English" is an overview of the sociolinguistic factors influencing how English is spoken in the United States. Differences according to sex and ethnic origin of speakers are highlighted, in particular the English of native Americans (= American Indians), Hispanics, Black Americans, and Appalachian whites. All of these are richly documented with methodologically solid studies carried out since the mid-1960's.

Toon includes interesting comments on the prescriptivist tendency in the American educational establishment and common definitions of, for example, "good English"' (214). 
One notable omission in Cassidy's and Toon's contributions is Dillard's (1975) creolist challenge to a dialect geography theory of the origins of American English. Dillard's work is however listed in the comprehensive bibliography, under "The United States".

David L. Lawton's "English in the Caribbean" presents, among other things, a nice table of linguistic and demographic facts of the Caribbean, whose uniqueness for the study of the origins of Jamaican Creole and questions its investigation raises with regard to larger questions of language around the world is again demonstrated. For example, the essence of language is brought into focus in these investigations. The reviewer, however, noticed but one reference to LePage's work in this region, which raises doubts about the breadth of treatment.

Loretto Todd's "The English Language in West Africa" is primarily a historical treatment of the entrance of English into West Africa. Of interest to the reviewer are the reported opinions of early English explorers on the alleged "corruption"' of the English language. There are examples of various West African English-based Pidgin languages, which can be compared with examples from the Caribbean and Papua New Guinea.

Ian F. Hancock and Rachel
Angogo's "English in East Africa" gives helpful comparisons between West and East Africa in the development of English. Useful questions are raised relative to the distinction between "error" and "features of local English." Four speech communities are defined according to social characteristics. There is a historical survey of English in East Africa, and a discussion of some of its characteristics. The samples cited indicate problems of description of the English of East Africa.

L.W. Lanham's 'English in South Africa" presents a demography of English speaking South Africa and describes patterns of use of English, alongside Afrikaans.

Braj B. Kachru's "South Asian English" is representative of his work which has a certain following. In discussions with other Indian scholars, one wonders how widely this descriptive view of things is held or would be supported among Indian linguists.

John T. Platt's "English in Singapore, Malaysia and Hong Kong' reveals the author's certain feel for historical aspects of the development of English in Singapore, Malaysia and Hong Kong. With regard to the linguistic description of English, however, having read most of the author's published work, the reviewer feels that, to date, the work presents interesting hypotheses, which ought to be 
established by means of rigorous quantitive sociolinguistic studies (ref. Anderson (1985).

Robert D. Eagleson's “English in Australia and New Zealand" is a concise summary of various writers on that subject which this reviewer has used in his course on varieties of English. The interrelation of history and language is nicely foregrounded with many examples. Professor Delbridge's work on pronunciation has been summarized in a useful manner, and the discussion of Australians' and non-Australians' attitudes toward Australians' distinctive pronunciation, with a short aside on the emergence of Strine (= stylized pronunciation of "Australian"), indicate a healthy Australian view of the situation laced with humor and pride.

Peter Muhlhausler's "Tok Pisin in Pupua New Guinea" presents another case study of pidgin and creole language situations, beginning with the origins of the name Tok Pisin (= "Talk Pidgin'), the inputs into the formation of the language, and down to the present difficultits of communication due to the development of an urban Tok Pisin which is significantly different from rural Tok Pisin. The section 'Language Planning and the Future of Tok Pisin' should be carefully read, not only for its factual content, but especially as a reminder of the social and personal conflicts inherent to all linguistic situations where there is rapid social change.
The section on "Suggested Readings" is divided into $15 \mathrm{sec}$ tions, not quite coinciding with the 15 contributions.

They are:

1. Bibliographies;

2. Dictionaries;

3. Sociolinguistics and the Sociology of Language;

4. English as a World Language;

5. Pidgin and Creole Languages;

6. England;

7. Scotland;

8. Ireland;

9. The United States;

10. Canada;

11. The Caribbean;

12. Africa;

13. South Asia;

14. Australia and New Zealand;

15. English and English-Based Pidgins in the Southwest Pacific.

The "Subject and Author Index" enabled the reviewer to locate people and topics easily.

In general, by way of summing up, although the relative value of the contributions differs, mainly due to the reasearch bases on hich they are built, the overall value of this collection of papers as an overview of what has been done in the field, with one notable exception (which will be discussed in the next paragraph), is immense. The style of presentation is unified and this makes comparisons on historical matters possible. 
The only serious disappointment in the compilation of articles, especially for the Southeast Asian audience, is the omission of English in the Philippines. How is it possible that such an omission could come about, given that Philippine linguists Sibayan, Gonzales, and Llamzon, to name only three, have produced quite a collection of works documentating English?

One of the difficulties of reading a volume such as this is that contributions differ in their bases from the solid, methodologically-sound to rather polemical treatments. This will, of course, be ferreted out by the diligent scholar with a solid foundation in linguistics. Perhaps it is a positive thing too that the diletante will also find grist for his mill.

There are few very minor typographical errors, one, for example, on page 315: the suprascript heading should read English in East Africa, not West, but these do not disturb the use of the book.

\section{References}

Anderson, Edmund A. 1985. Sociolinguistic surveys in Singapore. International Journal of the Sociology of Language 55, 89-114.

Dillard, J.L. 1975. All-American English. New York: Random House.

Hughes, Arthur and Trudgill, Peter. 1979. English Accents and Dialects. London: Edward Arnold.

Mazrui, Ali A. 1973. The English language and the origins of African nationalism. In Varieties of Present-Day English. Bailey, Richard W. and Robinson, Jay L., editors. New York: Macmillan Co., pp. 56-70. 